ROCZNIKI HUMANISTYCZNE

Tom LXVII, zeszyt $10-2019$

DOI: http://dx.doi.org/10.18290/rh.2019.67.10-3

IRENA CHAWRILSKA

\title{
INTERMEDIA W PROCESIE POZNAWANIA KULTURY PRZEZ UCZNIÓW Z DOŚWIADCZENIEM MIGRACJI
}

Nauczyciele języka polskiego jako obcego regularnie wykorzystują film jako narzędzie dydaktyczne podczas kursów języka polskiego jako obcego lub w pracy z obcokrajowcami studiującymi polonistykę ${ }^{1}$. Film na stałe zagościł na lekcjach języka polskiego zarówno w szkole, jak i na uniwersytecie. Wydaje się, że w świetle zmieniających się podstaw programowych ${ }^{2}$ i nowoczesnego dyskursu dotyczącego nauczania języka polskiego, powszechną formą kontaktu $\mathrm{z}$ filmem w szkole nie jest już tylko zbiorowe wyjście na ekranową adaptację lektury i okazjonalne pisanie recenzji ${ }^{3}$. Z uwagi na nieodwracalne procesy w kulturze i wymagania egzaminacyjne ${ }^{4}$ nawet nauczyciele tradycjonaliści rewidują swoje nastawienie do filmu. Film powinien jednak stanowić zaledwie element edukacji medialnej, którą zdefiniować można następująco: „kształtowanie umiejętności

Dr Irena Chawrilska - adiunkt w Katedrze Polonistyki Stosowanej w Instytucie Filologii Polskiej Uniwersytetu Gdańskiego, pracownik Centrum Kultury i Języka Polskiego dla Cudzoziemców Uniwersytetu Gdańskiego; e-mail: irena.chawrilska@ug.edu.pl

${ }^{1}$ Do regularnego wykorzystywania filmu na zajęciach skutecznie przekonuje A. Tambor w swojej rozprawie doktorskiej, proponując jednocześnie praktyczne rozwiązania, zob. A. TAMBOR, Film jako przedmiot i narzędzie nauczania kultury polskiej i języka polskiego jako obcego, http:// www.sbc.org.pl/Content/188016/doktorat3592.pdf. Na Uniwersytecie Gdańskim, gdzie od blisko 10 lat prowadzone są zajęcia z obcokrajowcami z Harbinu studiującymi język polski i kulturę polską, prowadzone są regularnie ćwiczenia, na których program przewiduje poznanie arcydzieł polskiego filmu. Przedmiot ten spotyka się z bardzo dobrym przyjęciem ze strony studentów z Chin.

${ }^{2} \mathrm{~W}$ podstawie programowej z 2012 r. znajdziemy propozycje filmów polskich reżyserów rekomendowanych do obejrzenia dla uczniów w zakresie podstawowym oraz listę filmów klasyków światowego kina w zakresie rozszerzonym, http://prawo.sejm.gov.pl/isap.nsf/download.xsp/ WDU20120000977/O/D20120977.pdf (dostęp: 31.01.2019).

${ }^{3}$ W. BoBı́́ski, Teksty w lustrze ekranu. Okołofilmowa strategia kształcenia literacko-kulturowego, Kraków: Universitas 2011, s. 12.

${ }^{4}$ Zmiana formuły egzaminu ustnego z języka polskiego od $2015 \mathrm{r}$. 
świadomego, krytycznego i selektywnego korzystania ze środków społecznego przekazu, w tym wychowanie do odbioru mass mediów" 5 . Zadaniem nauczyciela jest przygotowanie do umiejętnego korzystania ze środków masowego przekazu w języku polskim ${ }^{6}$. Propozycje scenariuszy przygotowane na potrzeby edukacji medialnej przez serwis Edukacja Medialna dotyczą wielu istotnych kwestii i mają na celu rozwijanie kluczowych kompetencji: korzystania z informacji, kultury i etyki komunikacji medialnej, kreatywnego korzystania z Internetu, bezpiecznego porozumiewania się, pracy i transakcji w środowisku cyfrowym ${ }^{7}$. Pozostaje jednak pewna niewykorzystana przestrzeń, dzięki której podczas zajęć w szkole można jednocześnie podnosić kompetencje uczniów w tym zakresie i otwierać ich na interpretację jako czynność pozwalającą odnaleźć się w świecie, porządkującą rzeczywistość, ułatwiającą budowanie relacji międzyludzkich, umożliwiającą udział w kulturze i jej rozumienie ${ }^{8}$. Za przestrzeń tę uznaję intermedia, rozumiane jako narzędzie dydaktyczne, będące fuzją różnych mediów wchodzących ze sobą w relacje w obrębie jednego komunikatu artystycznego. Dobrze zrealizowane zajęcia z wykorzystaniem sztuki tego typu mogą stać się materiałem do rozmowy, dialogowania z nauczycielem i grupą, a nade wszystko - zaczynem, wstępem do doświadczenia estetycznego, dzięki któremu uczeń zechce się otworzyć i wyrazić swoje zdanie podczas zajęć. Intermedia mogą zatem okazać się doskonałym narzędziem, które pozwoli uniknąć krępującej ciszy tak dobrze znanej w polskiej szkole, kiedy to uczniowie nie podejmują dialogu zaprojektowanego przez nauczyciela. Sytuacja ta nabiera nowego znaczenia, kiedy w sali lekcyjnej znajdują się obok polskich uczniów uczniowie z doświadczeniem migracyjnym, którzy nie rozumieją tekstu literackiego, nie zrozumieli jego adaptacji filmowej, a teksty ikoniczne, które z założenia mają ułatwiać lub wzbogacać interpretację literatury, wydają się uczniowi absurdalne i zupełnie niepowiązane z tym, co czytali wcześniej. Wprowadzenie dobrze skonstruowanych ćwiczeń, wykorzystujących świadomie intermedia, pozwoli nauczycielowi wprowadzić tekst kultury w dialog intersemiotyczny, a to z kolei

\footnotetext{
${ }^{5}$ http://edukacja-medialna.wyklady.org/ (dostęp: 09.01.2019).

${ }^{6}$ Niezwykle pomocny w tym celu jest serwis Edukacja Medialna, zawierający scenariusze, ćwiczenia i materiały do prowadzenia edukacji medialnej. Został opracowany w ramach projektu Cyfrowa Przyszłość i jest prowadzony przez Fundację Nowoczesna Polska pod honorowym patronatem Ministerstwa Edukacji Narodowej, Ministerstwa Kultury i Dziedzictwa Narodowego oraz Ministerstwa Administracji i Cyfryzacji, http://edukacjamedialna.edu.pl/info/o-nas/ (dostęp: 31.01.2019).

${ }^{7} \mathrm{http}: / /$ edukacjamedialna.edu.pl/kompetencje/ (dostęp: 31.01.2019).

${ }^{8}$ Interpretacja. Poradnik, http://bnd.ibe.edu.pl/files/upload/Interpretacja.\%20Poradnik_c433. pdf (dostęp: 31.01.2019).
} 
umożliwi uczniom z niską kompetencją językową uczestniczenie w odbiorze treści i znaczeń, które są przedmiotem lekcji.

Niniejsza analiza stawia sobie za cel refleksję nad rolą intermediów w procesie poznawania kultury polskiej i nauki języka polskiego przez uczniów z doświadczeniem migracji. Skuteczne wykorzystanie tego rodzaju tworów artystycznych w szkole podczas zajęć z języka polskiego, etyki, filozofii czy wiedzy o kulturze $^{9}$ może przyczynić się do rozwinięcia kompetencji medialnych, wizualnych (ang. media literacy i visual literacy) i interpretacyjnych ucznia, a także ułatwić mu rozpoczęcie procesu poznawania kultury polskiej, w tym literatury. Jest to możliwe tylko dzięki utrzymaniu poziomu motywacji ucznia do pracy, który często spada z powodu nieustannego kontaktu z niezrozumiałymi dla niego (pod względem formy, a nade wszystko - języka) tekstami kultury.

$\mathrm{Z}$ perspektywy neurodydaktyki wprowadzanie intermediów do procesu kształcenia ucznia z doświadczeniem migracyjnym ma też wpływ na pobudzenie neuronów w mózgu, od których zależy proces uczenia się, a łączenie informacji z emocjami, które niewątpliwie mogą wywołać różnego rodzaju ćwiczenia z intermediami, zwiększą zdolności poznawcze uczniów. Na efektywność zapamiętania natomiast wpływać będzie stymulacja wielozmysłowa, zwłaszcza wizualna i kinestetyczna ${ }^{10}$. Tego rodzaju działania powinny się znaleźć nie tylko na lekcjach języka polskiego w klasach z uczniem migracyjnym, ale przede wszystkim na dodatkowych zajęciach języka polskiego jako obcego i języka specjalistycznego, które od niedawna zapewnia uczniom z zagranicy polska szkoła ${ }^{11}$.

\section{INTERMEDIA W DIALOGU ZE WSPÓŁCZESNOŚCIĄ}

Uczestnictwo we współczesnej kulturze wymaga partycypacji w społeczeństwie sieciowym. Żyjemy w epoce konwergencji mediów, a nawet w erze transmediów,

\footnotetext{
${ }^{9} \mathrm{~W}$ podstawie programowej z 2018 r. nie ma już przedmiotu szkolnego ,wiedza o kulturze”.

${ }^{10}$ Por. M. ŻylinsKa, Neurodydaktyka. Nauczanie i uczenie się przyjazne mózgowi, Toruń: Wydawnictwo Naukowe UMK 2013, s. 91.

${ }^{11}$ Od roku szkolnego 2016/2017 obowiązuje Rozporządzenie Ministra Edukacji Narodowej z dn. 9 września 2016 r. w sprawie kształcenia osób niebędących obywatelami polskimi oraz osób będących obywatelami polskimi, które pobierały naukę w szkołach funkcjonujących w systemach oświaty innych państwa (Dz. U. poz. 1453). W stosunku do poprzednich regulacji nowe rozporządzenie uwzględnia reemigrantów powracających do polskiej rzeczywistości szkolnej. Dzięki temu uczniowie z doświadczeniem migracyjnym oraz ich nauczyciele zyskali możliwość otwierania oddziałów przygotowawczych w szkole, czyli zajęć z języka polskiego. Dla klas I-III prawo gwarantuje 20 godzin języka polskiego tygodniowo, dla IV-VI nie mniej niż 23, a dla licealistów nie mniej niż 26 godzin.
} 
w której transgresja staje się podstawowym materiałem kulturotwórczym. Szukamy międzykulturowych przejść, żeby pluralizować kulturę ponowoczesną ${ }^{12}$. Dlatego dzisiejsza twórczość artystyczna, prowadząca dialog ze współczesnością, jest: polifoniczna, wielotworzywowa, intermedialna, multimedialna, nieustannie próbująca oddać doświadczenie współczesnego świata ${ }^{13}$. Intermedialność jest kategorią zawierającą prefiks inter-, podobnie jak: intertekstualność, interaktywność, interfejs. Pojęcie ,intermedialność” charakteryzuje się relacyjnością, wyznaczoną przez 2 typy mediów, konstruujących nowy komunikat estetyczny. W przestrzeni „między” tworzą się nowe jakości ${ }^{14}$, dochodzi do wymiany między rozmaitymi mediami w sytuacji „skotłowania form”, jak trafnie określił ją Clifford Geertz ${ }^{15}$. Samo pojęcie intermedialności nie jest nowe, jego historia sięga roku 1965, kiedy to Dick Higgins napisał esej Intermedia, definiując je jako fuzję wielu mediów pierwotnie istniejących odrębnie ${ }^{16}$.

Za strategie intermedialne uznać można: przekraczanie ustalonych i uznawanych wcześniej podziałów, rozpoznawanie nowych możliwości powiązań i scalanie w zintegrowaną całość odmiennych składników wyjściowych ${ }^{17}$. Dzięki nim zostały zapoczątkowane głębokie przemiany w modelu odbioru sztuki, polegające na przeniesieniu punktu ciężkości z twórcy na odbiorcę. To odbiorca wypełnia percypowane dzieło sztuki swoim doświadczeniem. Za przykład może tu posłużyć happening, który uważa się za teatralizację sztuk plastycznych. Nawet jeżeli happening można nazwać teatrem plastyków, to zwraca on uwagę na teatralizację życia współczesnego i spektaklowy charakter współczesnej kultury,

${ }^{12}$ A. ZEIDLER-JANISZEWSKA, ,Kultura”, ,kultury”, ,,transkulturowość”. Kilka uwag o pojęciach i nie tylko, w: Od logiki do estetyki, red. R. Kubicki, P. Zeidler, Poznań: Wydawnictwo Fundacji Humaniora 1997, s. 164-165.

${ }^{13}$ R. KluszcZyŃSKi, Słowo wstępne, w: (Nie)obecne granice, red. K. Kuropatwa, D. Rode, Kraków: Wydawnictwo Rabid 2003, s. 9.

${ }^{14}$ „Obecnie możemy obserwować, jak relacyjna sfera „między” autonomizuje się, pierwotne punkty, punkt wyjścia i punkt dojścia zanikają, przestają mieć jakiekolwiek znaczenie dla jej dookreślenia. Pojawiają się nowe metafory dla uchwycenia znaczenia tej samoistnej przestrzeni „między”: metafora nomadyzmu, internetowej nawigacji, interfejsów rozumu transwersalnego, rhizomatycznej sieci, intertekstualności, intermedialności, interaktywności, metafora „odysei” wreszcie - ale swoistej, bo pozbawionej planu powrotu do Itaki”. K. WiLKoszEwSKa, Prefiksu w roli wyznaczników współczesności, w: Intermedialność w kulturze końca XX wieku, red. A. Gwóźdź, S. Krzemień-Ojak, Białystok: Wydawnictwo Uniwersyteckie „Trans-humana” 1998, s. 14.

${ }^{15}$ C. Geertz, O gatunkach zmaconych (Nowe konfiguracje myśli społecznej), w: Postmodernizm. Antologia przekładów, red. R. Nycz. Kraków: Baran i Suszczyński 1997, s. 215.

${ }^{16}$ D. Higgins, Horyzonty, w: Tenże, Nowoczesność od czasu postmodernizmu oraz inne eseje, wybór, opracowanie i posłowie P. Rypson, Gdańsk: Słowo/obraz terytoria 2000, s. 111.

${ }^{17}$ M. Hopfinger, Doświadczenia audiowizualne. O mediach w kulturze współczesnej, Warszawa: Wydawnictwo Sic! 2003, s. 72. 
a nie realizuje założenia sztuki teatralnej. Elementy sztuk plastycznych i teatru w jednym wydarzeniu artystycznym są w przypadku happeningu efektem zamierzonej strategii podwójnego kodowania. W procesie interpretacji happeningu istotne okazują się skutki interakcji mediów niezależnych uprzednio względem siebie i nowe jakości powstające $\mathrm{w}$ procesie przekraczania-rozpoznawania-scalania intermedium i wypełniania go przeżyciami odbiorcy. Intermedialność byłaby w tym kontekście cechą najnowszej sztuki, już nie tylko II Wielkiej Awangardy, ale dzisiejszej sztuki wydarzającej się w środowisku sieciowym, narzucającej multisensoryczną formę komunikacji, zrywającej jednocześnie z neutralnością odbiorcy. Intermedia stanowią efekt doświadczenia współczesnego świata, bycia w sytuacji medialnej i zmediatyzowanej. Samo intermedium staje się często jedynie inspiracją do wypełnienia go treścią, interpretacją opartą na własnym doświadczeniu rzeczywistości, co w kontekście szkolnym może okazać się zbawienne dla ucznia z doświadczeniem migracji, który niekoniecznie dobrze mówi po polsku. Uczeń może wykorzystać kompetencje medialne i wizualne, żeby zinterpretować tego rodzaju tekst kultury ${ }^{18}$, a przy okazji rozwijać kompetencje językowe podczas zajęć, na których pojawia się sztuka intermedialna.

\section{UCZEŃ DOŚWIADCZAJĄCY BYCIA „MIĘDZY”}

W polskiej rzeczywistości edukacyjnej uczeń z doświadczeniem migracyjnym stosunkowo niedawno został zauważony jako ten o specjalnych potrzebach edukacyjnych. Zagadnienie to podejmuje Przemysław Gębal w książce Podstawy dydaktyki języka polskiego jako drugiego. Podejście integracyjno-inkluzyjne ${ }^{19}$. Współcześnie na gruncie polskim mówimy o glottopedagogice,

${ }^{18}$ Film w kontekście intermediów również nie zostaje zapomniany. Refleksje niemieckich teoretyków (Joachim Paech, Knut Hickethier, Jürgen E. Müller, Yvonne Spielmann, Michael Peters) dotyczące intermediów dotyczą sztuki filmowej i jej relacji z innymi mediami. K. ChMielecki, Intermedialność jako fenomen ponowoczesnej kultury, „Kultura Współczesna” 2 (2007), 118-137.

${ }^{19}$ Badacz ukazuje proces przejścia od pedagogiki dla cudzoziemców do pedagogiki międzykulturowej na gruncie niemieckim. Pedagogika dla cudzoziemców koncentrowała się na asymilacji cudzoziemców i była zorientowana na deficyty językowe. Brakowało tu glottopedagogicznego otwarcia na różnorodność językową i kulturową. Panaceum na problemy edukacji osób z doświadczeniem migracyjnym nie okazała się również pedagogika międzykulturowa, krytykowana za podkreślanie różnic kulturowych i niepodnoszenie innych istotnych kwestii. Następną fazą rozwoju była pedagogika różnorodności społeczno-kulturowej, językowej, społeczno-ekonomicznej czy genderowej, skrytykowana za segregowanie poszczególnych osób z uwagi na ich pewne cechy. Ostatnia z wyróżnionych i opisanych przez Gębala faz stawia sobie za cel respektowanie różnorodności celów i postaw, jeśli nie są one w sprzeczności z wartościami uniwersalnymi. Dzięki 
czyli nauczaniu języków, mające na celu wychowanie interkulturowe do życia w wielojęzycznej i wielokulturowej Europie. Badacz podkreśla, że profesjonalne działania na polu nauczania języka polskiego jako obcego i języka polskiego jako drugiego ${ }^{20}$ wymagają współpracy glottodydaktyków polonistycznych oraz pedagogów i psychologów międzykulturowych. Polska szkoła stanęła przed wyzwaniem zapewnienia wsparcia uczniom z doświadczeniem migracji nie tylko w ramach edukacji włączającej, lecz także w nauce języka polskiego i kultury polskiej. Istotne jest uczenie języka polskiego jako narzędzia umożliwiającego komunikację, poznawanie świata i nawiązywanie w nim relacji. W sytuacji szkolnej ważne jest też przygotowanie ucznia do skutecznego wykorzystywania tekstów specjalistycznych, nauki języka w taki sposób, żeby uczeń był w stanie przyswajać wiedzę i konstruować wypowiedzi w języku specjalistycznym $^{21}$.

W procesie poznawania kultury polskiej w warunkach szkolnych uczniowi niezbędny jest język specjalistyczny: nauki o literaturze i nauki o języku, a także - wiedzy o kulturze, żeby skutecznie przygotować się do egzaminu maturalnego, który nadal sprawdza opanowanie zagadnień znajdujących się w podstawie programowej z 2012 r. Stawia ona uczniowi następujące wymagania ogólne: 1. Odbiór wypowiedzi i wykorzystanie zawartych w niej informacji, 2. Analiza i interpretacja tekstów kultury, 3. Tworzenie wypowiedzi ${ }^{22}$.

Już na poziomie analizy wymagań ogólnych nietrudno się zorientować, że zakładane wyniki są bardzo trudne do osiągnięcia przez nierodzimych użytkowników języka. Biorąc pod uwagę opisany w glottodydaktyce dwuletni czas potrzebny do tego, by uczniowie opanowali język na poziomie komunikacyjnym

takiemu podejściu dochodzi do wypracowania standardów kształcenia kulturowego i językowego uwzględniających kwestię wartości i wartościowania. P. GęBal, Podstawy dydaktyki języka polskiego jako drugiego. Podejście integracyjno-inkluzyjne, Kraków: Księgarnia Akademicka 2018.

${ }^{20}$ Język drugi to nierodzimy język użytkownika i jednocześnie oficjalny/urzędowy kod, posiadający status prawny w miejscu osiedlenia. Jest to również język codziennej komunikacji, a dla młodego pokolenia to język edukacji szkolnej. E. LipińsKa, A. Seretny, Od języka pierwszego przez odziedziczony i drugi do języka ojczystego - o polszczyźnie polskiego ucznia imigrantal reemigranta, w: Edukacja wobec migracji. Konteksty glottodydaktyczne i pedagogiczne, red. P. Gębal, Kraków: Księgarnia Akademicka 2018, s. 92.

${ }^{21}$ Tego rodzaju propozycją jest metoda JES-PL, http://fundacjareja.eu/wp-content/uploads/2015/11/Metodyka-nauczania-je\%CC\%A8zyka-edukacji-szkolnej-ucznio\%CC\%81w-z-dos\%CC\%81wiadczeniem-migracji.-Metoda-JES-PL-matematyka.pdf (dostęp: 27.01.2019).

${ }^{22} \mathrm{http} / / / \mathrm{ww}$ w.bc.ore.edu.pl/dibra/docmetadata?id=232\&from=pubindex \&dirids $=11 \& 1 \mathrm{p}=6$. W 2022 r. po raz ostatni odbędzie się matura przygotowana zgodnie z wymaganiami podstawy programowej minister K. Hall, a w 2023 r. po raz pierwszy matura odbędzie się zgodnie z podstawą programową przygotowaną przez minister A. Zalewską. 
i zakładane 5-7 lat, żeby opanować język edukacji szkolnej ${ }^{23}$, proces kształcenia musi zostać zaprojektowany w taki sposób, żeby uczeń z doświadczeniem migracji na koniec szkoły średniej miał szansę zrealizowania podstawy programowej z języka polskiego (na poziomie podstawowym).

Strategie intermedialne opierające się na opisanej wyżej triadzie: przekroczenie-rozpoznanie-scalenie stanowią odbicie wielopoziomowej złożoności, hybrydyczności i niejasności rzeczywistości ponowoczesnej. Intermedialne teksty kultury uformowane są w taki sposób, że odbiorca nie może dotrzeć do jednoznacznego sensu, a często nawet kilku współistniejących, wypełnia je więc swoim doświadczeniem, treścią zaczerpniętą z własnego bycia w świecie. Komunikat artystyczny, jakim są poszczególne intermedia, ukazuje aporetyczność i nieokreśloność na poziomie rzeczywistości, w której niemożliwe jest uchwycenie jednoznacznego sensu żadnego zjawiska. Próba zintegrowania różnych mediów ujawnia aporetyczność rzeczywistości, ponieważ intermedia nie są w stanie oddać złożoności świata. Twórczość, która nie została zaprojektowana po to, żeby jednoznacznie opisać fragment świata, czasem przemawia do umysłu odbiorcy, ale równie często jest to doświadczenie pozarozumowe intensyfikujące sposób widzenia świata i dezautomatyzujące percepcję. Uczeń doświadczający intermediów ma szansę na refleksję dotyczącą współczesnego świata i własnej hybrydowej tożsamości.

Poniżej przedstawiam 3 propozycje ${ }^{24}$ wykorzystania intermediów w praktyce szkolnej, które służą edukacji polonistycznej, ale jednocześnie mogą zostać połączone z wiedzą o kulturze, filozofią czy etyką w ramach warsztatów czy bloków przedmiotowych ${ }^{25}$. Przykłady intermedialnych tekstów kultury należy dobierać starannie, mając na uwadze tematy tabu w danej kulturze, różnice kulturowe i potrzeby edukacyjne poszczególnych uczniów. Każda z lekcji skonstruowana jest według nadrzędnej struktury:

${ }^{23}$ M. PamuŁa-Behrens, M. Szymańska, Metoda JES-PL. Nauczanie języka edukacji szkolnej uczniów z doświadczeniem migracji, „Języki Obce w Szkole” 2018, nr 2, http://jows.pl/sites/ default/files/wydania/jows-2-2018_internet_0.pdf (dostęp: 25.12.2018).

${ }^{24}$ Propozycje te nie są kompletnymi scenariuszami lekcji, a jedynie pomysłami na lekcje, które nauczyciel w zależności od potrzeb grupy może wypełnić własnym przykładem intermedialnego tekstu kultury i ćwiczeniami.

${ }^{25}$ Poszczególne wymagania z przedmiotów humanistycznych mogą być realizowane w systemie blokowym, co uczniowi z doświadczeniem migracji ułatwi rozwój kompetencji językowych i zdobywanie wiedzy przedmiotowej. Brak umiejętności językowych blokuje przyswajanie treści z zakresu edukacji polonistycznej, filozoficznej czy kulturowej. W zblokowanym cyklu nauczania łatwiej jest poznawać język edukacji szkolnej, czyli język podręczników szkolnych i ten wymagany do tworzenia tekstów pisanych i czytania tekstów specjalistycznych. 
Wstępne przygotowanie: prezentacja twórcy lub projektu artystycznego omawianego w dalszej części lekcji, ćwiczenia leksykalne.

1. Lektura/odbiór intermedialnego tekstu kultury.

2. Ćwiczenia właściwe: sprawdzające rozumienie tekstu, ćwiczenia leksykalno-gramatyczne; mówienie: rozmowa z uczniami i uczniów między sobą, przetwarzanie doświadczenia estetycznego i interpretacja tekstu intermedialnego.

3. Przygotowanie tekstu nawiązującego do omawianego tekstu intermedialnego ${ }^{26}$.

\section{PREZENTUJĄC PRZEŻYCIE ESTETYCZNE}

Przygotowanie: zaprezentowanie działalności grupy Twożywo ${ }^{27}$, ćwiczenia wprowadzające/przypominające słownictwo dotyczące opisu dzieła sztuki ${ }^{28}$.

${ }^{26}$ Realizowane wymagania z podstawy programowej. Uczeń: prezentuje własne przeżycia wynikające z kontaktu z dziełem sztuki JP II.1.1); wstępnie rozpoznaje każdy z omawianych utworów JP II 1.1), 2), 3); odczytuje sens całego tekstu i objaśnia funkcje i znaczenia poszczególnych części danego tekstu oraz użytych w nim środków stylistycznych i retorycznych JP I 1.1); rozpoznaje typ nadawcy i adresata tekstu JP I 1.3); wypowiada się na temat dzieła sztuki, używając swoistych dla tej dyscypliny pojęć WOK 2.2); snuje refleksję nad celem i sensem ludzkiej egzystencji; rozważa problem szczęścia w życiu ludzkim oraz rozwoju moralnego i duchowego człowieka jako osoby E5; analizuje wpisany w analizowane teksty wymiar moralny życia człowieka E8; interpretuje różne efekty działalności artystycznej z najbliższego otoczenia (np. murale, graffiti, kościół) WOK 3.4); przygotowuje prezentację ustną i multimedialną, WOK 2.1), 3), 9); przygotowuje pisemnie: interpretację, opis dzieła sztuki oraz ustną interpretację jednego $\mathrm{z}$ analizowanych utworów JP III 1.1); dostrzega w świecie konflikty wartości, które były charakterystyczne w literaturze i sztuce romantycznej JP II 4.4).

${ }^{27}$ Grupę Twożywo tworzyli Mariusz Libel i Krzysztof Sidorek. Grupa funkcjonowała od 1995 roku do lutego 2011. Na stronie www grupy znajduje się następujący komunikat: „Z dniem 1 marca 2011 grupa Twożywo kończy swoją działalność. Strona będzie dostępna dopóki domena art.pl oraz serwery hostujące będą działać i nas gościć. Dziękujemy wszystkim, z którymi mieliśmy okazję współpracować, i tym, którzy od lat śledzili z uwagą nasze poczynania" [komunikat z 19 lutego 2011], http://www.twozywo.art.pl/twzw.php?d (dostęp: 30.01.2019). Początkowo grupa funkcjonowała pod nazwą Pinokio - do 1998 r. Wówczas jej członkiem był również Robert Czajka. Artyści koncentrowali się w tamtym okresie działalności na tworzeniu murali, ulotek, wlepek, które umieszczali w środkach transportu miejskiego, oraz plakatów. W swojej twórczości grupa Twożywo podejmowała tematykę społeczną i polityczną. W warstwie formalnej artyści odwołują się do estetyki z pierwszej połowy XX wieku, ich prace stanowią układy liter i schematycznych, często biało-czarnych rysunków, np. Antychryst będzie artyst z 1998 r. Od roku 2000 artyści zaczęli prezentować swoją twórczość na billboardach zarówno w ramach Galerii Zewnętrznej AMS, jak i w stałych miejscach - na billboardach przy ul. Kopernika i ul. Koszykowej. Mimo oporów, zaczęli również pokazywać swoje prace w galeriach. 


\section{Opis zajęć:}

1. Zaprezentowanie wybranego muralu grupy (jeśli to możliwe w przestrzeni miejskiej), np. czystość jest? (http://twozywo.art.pl./twzw.php?1me);

2. Luźna dyskusja, w trakcie której chętni uczniowie opowiadają o swoich doświadczeniach i sposobie rozumienia muralu;

3. Praca w grupach, podczas której uczniowie analizują kształty, linie, funkcje kolorów, liter, wyrazów, poszczególne elementy kompozycji zastosowane przez artystów;

4. Wprowadzenie elementów analizy dzieła sztuki (opisu dzieła sztuki): informacja o autorze dzieła, tytule, epoce i nurcie artystycznym, przedstawienie szerszego kontekstu jego powstania; określenie, jaką techniką posłużył się artysta, jakie materiały wykorzystał itp.; omówienie treści dzieła, jego kompozycji (co znajduje się na pierwszym planie i kolejnych), nastroju, kolorystyki itp., przypisanie znaczenia tym elementom; interpretacja dzieła (omówienie symboliki, znaczenia, sposobu odbioru);

5. Ćwiczenia z leksyki i struktur zdaniowych koniecznych do skonstruowania opisu dzieła sztuki (np. plan, treść, kompozycja, symbol, znaczenie, technika malarska; na pierwszym planie, na drugim planie, na środku, z prawej i lewej strony, artysta przedstawił, dzieło znajduje się, zawiera, przedstawia);

6. Zadanie dla uczniów: przygotowanie opisu wybranego muralu grupy Twożywo (spośród trzech zaproponowanych) lub innego muralu znalezionego w przestrzeni miejskiej.

Podsumowanie: Uczniowie wspólnie z nauczycielem przedstawiają wnioski z pracy na zajęciach w formie notatki wizualnej. Ustalają, na czym polega specyfika prac artystów z grupy Twożywo, uznawanej za element życia społecznego. Wspólna interpretacja powinna doprowadzić do następujących wniosków:

1. Billboard został przysposobiony do przekazywania komunikatów estetycznych, tworzy konteksty w powiązaniu z otaczającą go przestrzenią miejską i stawia przechodniom rozmaite pytania. Twórczość grupy Twożywo wchodzi w relacje z miejskim kontekstem, a język staje się w tych przedsięwzięciach jednym ze środków komunikacji.

2. Formalnie prace te nie różnią się od reklamy, ponieważ funkcjonują na billboardach, obraz jest w podobny sposób sprzęgnięty ze słowem, charakteryzuje się lakonicznością i formą sprowadzoną do minimum.

\footnotetext{
${ }^{28}$ Należy zwrócić uwagę uczniów, że artyści celowo zapisują nazwę grupy artystycznej z błędem ortograficznym, a w grupach na niższym poziomie zaawansowania lepiej unikać zapisu nazwy grupy, żeby nie zaburzać procesu nauki polskiej normy ortograficznej.
} 
3. W odróżnieniu od reklamy sztuka grupy Twożywo funkcjonująca na billboardach nie pełni funkcji perswazyjnej. W swoich przedsięwzięciach artyści jednocześnie odwołują się do rozwiązań stosowanych przez reklamę i nawiązują do tradycji poezji eksperymentalnej, ponieważ koncentrują się na strukturze języka i dzięki grze słów z obrazem demaskują różnego rodzaju problemy społeczne. Weryfikacja efektów kształcenia przez nauczyciela: ocena wypowiedzi ucznia, ocena skuteczności dyskusji z pozostałymi uczniami, ocena pracy pisemnej.

\section{INTERPRETUJĄC TEKST/OBRAZ}

Przygotowanie: Zaprezentowanie projektu Loesje ${ }^{29}$, ćwiczenia wprowadzające/ powtarzające słownictwo związane $\mathrm{z}$ interpretacją tekstu poetyckiego.

\section{Opis zajęć:}

1. Zaprezentowanie wybranej Loesje: MOJA MOWA/ NIE/ PODLEGŁA/ NIENAWIŚCI (http://www.loesje.pl/images/stories/plakatypdf/2018/Moja_mowa.pdf);

2. Luźna dyskusja, w trakcie której chętni uczniowie opowiadają o swoich doświadczeniach i sposobie rozumienia tekstu/obrazu;

3. Analiza kompozycji, układu wyrazów i poszczególnych liter w tekście/obrazie, opis funkcji przestrzeni, w której została umieszczona Loesje; negocjowanie znaczenia tekstu/obrazu;

4. Wprowadzenie leksyki i struktur zdaniowych umożliwiających zwerbalizowanie interpretacji Loesje;

5. Ćwiczenia ugruntowujące leksykę i struktury zdaniowe konieczne do przygotowania ustnej interpretacji;

6. Zadanie dla uczniów: przygotowanie interpretacji wybranej Loesje.

Podsumowanie: Wnioski z analizy i interpretacji powinny doprowadzić do przekonania, że do sensu tekstu/obrazu odbiorca dochodzi inaczej niż w przypadku poezji tradycyjnej. Z fermentu intelektualnego lat 50. i 60. wyłoniły się utwory, które składały się z kilku liter, jednego wyrazu, czasem zaledwie kilku słów, a finalnie otrzymaliśmy spektakle, w których słowo i eksploracja jego materialności: wizualności i dźwięku stają się zaczynem performansów, w których odbiorca

\footnotetext{
${ }^{29}$ Loesje [luszje] to projekt artystyczny pochodzący z Holandii (data powstania: 24.11.1983 r.), powstał jako odpowiedź na problemy związane z sytuacją polityczną Holandii w latach 80 . XX wieku. Projekt skupia grupę osób działających na całym świecie w celu szerzenia wolności słowa, tolerancji, kreatywności. Dziś Loesje działa w kilkudziesięciu krajach na całym świecie, w Polsce pierwsza publikacja związana z projektem powstała w roku 2006. Działacze związani z projektem prowadzą szkolenia, międzynarodowe wymiany i warsztaty kreatywnego pisania tekstów, http:// www.loesje.pl/index.php?option=com_content\&view $=$ article \&id=7\&Itemid=8 (dostęp: 31.01.2019).
} 
może uczestniczyć. Wiersze eksperymentalne stały się spektaklami, a istotną rolę odgrywa w nich rytm ułożenia słów na stronie - wykorzystanie przestrzeni strony oraz rytm słów-dźwięków wypowiadanych przez artystę. Przemiany poezji eksperymentalnej polegały na rozszerzaniu znaczenia poezji i jej wchodzeniu w relacje z rozmaitymi dziedzinami sztuki, żeby jeszcze lepiej oddać doświadczenie ponowoczesnej rzeczywistości. Docieranie do istoty tego rodzaju dzieła wydaje się niemożliwe, a aporetyczność stanowi jego cechę konstytutywną. Tym samym poezja eksperymentalna wpisuje się w procesy zachodzące obecnie w kulturze.

Weryfikacja procesu kształcenia: ocena wypowiedzi ucznia, ocena skuteczności dyskusji z pozostałymi uczniami, ocena ustnej interpretacji.

\section{ROZMAWIAJĄC O WARTOŚCIACH}

Przygotowanie: prezentacja założeń nurtu art\&science ${ }^{30}$, ćwiczenia wprowadzające leksykę związaną z wartościami i wartościowaniem.

\section{Opis zajęć:}

1. Zaprezentowanie projektu Diane Gromali ${ }^{31}$ Dancing with the Virtual Derwish ${ }^{32}$;

${ }^{30}$ Są to projekty o charakterze transdyscyplinarnym, łączące kompetencje artystyczne, naukowe i inżynierskie. Działalność tego rodzaju prowadzona jest w multikompetencyjnych zespołach twórczych, których celem jest poszerzanie granic sztuki przy pomocy teorii naukowych. Sztuka i nauka uzupełniają się i wchodzą w twórczą interakcję, tworząc zarazem nowy sposób uobecniania się hybrydyczności w kulturze. Czerpią zarówno z poznania naukowego, jak i z doświadczenia artystycznego. Artystom i naukowcom pracującym wspólnie przyświeca kilka celów. Pierwszym z nich jest przybliżenie odbiorcy sztuki skomplikowanych problemów współczesnej nauki i kultury. Zdarza się, że za pośrednictwem sztuki inicjuje się społeczną debatę dotyczącą relacji zaawansowanej technologii i współczesnej kultury. Artyści i naukowcy prowadzą również wspólnie prace badawczo-artystyczne, za pośrednictwem których poszukują nowych strategii twórczych we współczesnej kulturze. Sztuka i nauka mogą tworzyć również wspólną refleksję dotyczącą krytycznych metod i procedur, którymi posługuje się nauka i inżynieria wobec wyzwań współczesnego społeczeństwa.

${ }^{31}$ Diane Gromala jest profesorem w School of Interactive Arts and Technology na Uniwersytecie Simona Frasera w Kanadzie. Kieruje grupą badawczą The Transforming Pain Research Group, która zajmuje się wykorzystaniem immersyjnych i wirtualnych przestrzeni w leczeniu chronicznego bólu, łącząc je z medytacją czy biofeedbackiem, a także z robotyką, wizualizacjami i mediami społecznościowymi. Gromala osobiście zmaga się z przewlekłym bólem, uważa, że dzięki zanurzaniu podmiotu w wizualnych projekcjach można obniżyć jego poziom. Badaczka razem ze swoim zespołem pracuje nad immersyjnymi projektami, które wykorzystywane są w terapii redukcji stresu, niwelowaniu bólu po chemioterapii u dzieci i bólu chronicznego. Wykorzystywane są w wielu szpitalach i klinikach na całym świecie. Jednym z pierwszych projektów Gromali w technologii VR jest Dancing with the Virtual Derwish.

${ }^{32}$ Można zobaczyć, na czym polega owa wizualizacja w niniejszym filmie, https://www. youtube.com/watch?v=EIQw_QTshLU (dostęp: 15.05.2016). 
2. Luźna dyskusja, w trakcie której chętni uczniowie opowiadają o swoich doświadczeniach i sposobie rozumienia projektów artystycznych w technologii VR;

3. Dyskusja zaprojektowana i moderowana przez nauczyciela dotycząca emocji, które budzi w uczniach projekt Diane Gromali i znaczenia nurtu art\&science we współczesnym świecie;

4. Ćwiczenia wprowadzające/powtarzające słownictwo i struktury zdaniowe umożliwiające zwerbalizowanie interpretacji projektu Gromali;

5. Ćwiczenia ugruntowujące leksykę i struktury zdaniowe konieczne do przygotowania ustnej interpretacji Dancing with the Virtual Derwish;

6. Zadanie dla uczniów: przygotowanie prezentacji multimedialnej dotyczącej projektu artystycznego z pogranicza sztuki i nauki lub bio-art-u.

Podsumowanie: Uczniowie wspólnie dochodzą do wniosku, że technologia VR i sztuka interaktywna wykorzystują bardzo skomplikowane technologie, które mogą być skuteczne w leczeniu bólu o wiele bardziej niż podawanie silnych leków przeciwbólowych. Kluczem do pokonania chronicznego bólu nie jest ucieczka przed cielesnymi ograniczeniami (disembodiment), lecz stan ponownego wcielenia (re-embodiment) za pośrednictwem zanurzenia w cyfrowych obrazach. Owo zanurzenie polega na doświadczaniu, które zmienia świadomość, w pewnym sensie rozprasza i fragmentaryzuje podmiotowość. Doświadczenia immersyjne, zmysłowe zanurzenie w innym świecie, karmienie umysłu iluzją, że doświadczamy czegoś rzeczywistego, podczas gdy mamy do czynienia z symulacją, jest perspektywą bardzo pociągającą.

Weryfikacja efektów kształcenia: ocena przygotowania i wygłoszenia prezentacji, ocena prezentacji multimedialnej, ocena treści wypowiedzi uczniów.

\section{PODSUMOWANIE}

Intermedia, dialogujące z rzeczywistością współczesną i oddające w swojej strukturze jej hybrydyczność i niestałość, mogą stanowić adekwatny materiał na lekcję języka polskiego (filozofii, etyki, wiedzy o kulturze), podczas której nie staną się tylko elementem uatrakcyjniającym zajęcia. Ich prymarną funkcją nie jest bycie materiałem do ćwiczeń leksykalnych i gramatycznych, lecz prowokowanie do pytań o świat współczesny. Strategie intermedialne polegające bowiem na: przekraczaniu jednego medium, rozpoznawaniu potencjału sfery bycia między dwoma mediami i scalaniu dwóch odrębnych mediów, stanowią odbicie rzeczywistości ponowoczesnej i jednostki, która nieustannie przebudowuje swoją tożsamość. Uczeń z doświadczeniem migracji, który zmienia miejsce 
zamieszkania, przekracza granice swojej kultury, żeby rozpoznać wartość bycia między dwiema rzeczywistościami kulturowymi i spróbować ukonstytuować, scalić swoją tożsamość, może zostać wytrącony z przyzwyczajeń poznawczych podczas zajęć opartych na intermedialnych tekstach kultury. Intermedia mogą się okazać skuteczniejsze niż tradycyjne teksty literackie, a nawet arcydzieła literatury, ponieważ odwołują się do uczniowskiego doświadczenia świata współczesnego, są bardziej uniwersalne i często transkulturowe. Mogą też być kontrowersyjne, poruszać problemy bardzo bliskie młodzieży i jednocześnie być wyrażone w zrozumiałym dla nich języku wizualnym i medialnym. Do odczytania i zrozumienia takich tekstów nie jest potrzebny złożony kontekst kulturowy, historyczny czy polityczny. Uczniowi o kompetencjach wizualnych i medialnych łatwiej jest zdać sprawę z własnego doświadczenia estetycznego na podstawie intermedialnego tekstu kultury i wyrazić opinię na jego temat niż stworzyć wypowiedź dotyczącą jednego z arcydzieł literatury polskiej, wymagającego licznych procesów adaptacyjnych ${ }^{33}$.

\section{BIBLIOGRAFIA}

BoBIŃSKi W., Teksty w lustrze ekranu. Okołofilmowa strategia kształcenia literacko-kulturowego, Kraków: Universitas 2011.

Chmielecki K., Intermedialność jako fenomen ponowoczesnej kultury, „Kultura Współczesna” 2 (2007), s. 118-137.

Geertz C., O gatunkach zmaconych (Nowe konfiguracje myśli spolecznej), w: Postmodernizm. Antologia przekładów, red. R. Nycz. Kraków: Baran i Suszczyński 1997.

GĘBAL P., Podstawy dydaktyki języka polskiego jako drugiego. Podejście integracyjno-inkluzyjne, Kraków: Księgarnia Akademicka 2018.

Hajduk-Gawron W., Arcydzieła literatury polskiej w praktyce glottodydaktycznej. Zaadaptować czytelnika i tekst, w: Adaptacje I. Język - Literatura - Sztuka, red. W. Hajsuk-Gawron, A. Madei, Katowice: Uniwersytet Śląski w Katowicach 2013, s. 353-366.

Higgins D., Nowoczesność od czasu postmodernizmu oraz inne eseje, wybór, opracowanie i posłowie P. Rypson, Gdańsk: Słowo/obraz terytoria 2000.

Hopfinger M., Doświadczenia audiowizualne. O mediach w kulturze współczesnej, Warszawa: Wydawnictwo Sic! 2003.

KLuszczyński R., (Nie)obecne granice: szkice o obliczach transgresji, red. K. Kuropatwa, D. Rode, Kraków: Rabid 2003.

${ }^{33}$ W. HAJduk-Gawron, Arcydzieła literatury polskiej w praktyce glottodydaktycznej. Zaadaptować czytelnika i tekst, w: Adaptacje I. Język - Literatura-Sztuka, red. W. Hajsuk-Gawron, A. Madei, Katowice: Uniwersytet Śląski w Katowicach 2013, s. 362. 
LipińsKa E., Seretny A., Od języka pierwszego przez odziedziczony i drugi do języka ojczystego - o polszczyźnie polskiego ucznia imigranta/reemigranta, w: Edukacja wobec migracji. Konteksty glottodydaktyczne i pedagogiczne, red. P. Gębal, Kraków: Księgarnia Akademicka 2018, s. 83-101.

Pamula-Behrens M., Szymańska M., Metoda JES-PL. Nauczanie języka edukacji szkolnej uczniów z doświadczeniem migracji, „Języki Obce w Szkole” 2018, nr 2, s. 5-10, http://jows. pl/sites/default/files/wydania/jows-2-2018_internet_0.pdf (dostęp: 25.12.2018).

TAмBOR A., Film jako przedmiot i narzędzie nauczania kultury polskiej i języka polskiego jako obcego, praca doktorska, Uniwersytet Śląski 2015, http://www.sbc.org.pl/Content/188016/ doktorat3592.pdf (dostęp: 20.08.2019).

Wilkoszewska K., Prefiksy w roli wyznaczników współczesności, w: Intermedialność w kulturze końca XX wieku, red. A. Gwóźdź, S. Krzemień-Ojak, Białystok: Wydawnictwo Uniwersyteckie „Trans-humana” 1998.

Zeidler-JANisZewsKa A., „,Kultura”, ,kultury”, ,transkulturowość”. Kilka uwag o pojęciach i nie tylko, w: Od logiki do estetyki, red. R. Kubicki, P. Zeidler, Poznań: Wydawnictwo Fundacji Humaniora 1997, s. 158-169.

ŻYlińsKa M., Neurodydaktyka. Nauczanie i uczenie się przyjazne mózgowi, Toruń: Wydawnictwo Naukowe UMK 2013.

\section{NETOGRAFIA}

http://www.loesje.pl/index.php?option=com_content\&view=article\&id=7\&Itemid=8 (dostęp: 31.01.2019).

https://www.youtube.com/watch?v=EIQw_QTshLU (dostęp: 15.05.2016).

http://www.twozywo.art.pl/twzw.php?d (dostęp: 31.01.2019).

http://fundacjareja.eu/wp-content/uploads/2015/11/Metodyka-nauczania-je\%CC\%A8zyka-edukacji-

-szkolnej-ucznio\%CC\%81w-z-dos\%CC\%81wiadczeniem-migracji.-Metoda-JES-PL-matema-

tyka.pdf (dostęp: 27.01.2019).

http://www.bc.ore.edu.pl/dlibra/docmetadata?id=232\&from=pubindex \&dirids=11\&lp=6

http://bnd.ibe.edu.pl/files/upload/Interpretacja.\%20Poradnik_c433.pdf (dostęp: 31.01.2019).

http://edukacjamedialna.edu.pl/info/o-nas/ (dostęp: 31.01.2019).

http://edukacja-medialna.wyklady.org/ (dostęp: 09.01.2019)

http://prawo.sejm.gov.pl/isap.nsf/download.xsp/WDU20120000977/O/D20120977.pdf (dostęp:

31.01.2019).

\section{INTERMEDIA W PROCESIE POZNAWANIA KULTURY POLSKIEJ PRZEZ UCZNIÓW Z DOŚWIADCZENIEM MIGRACJI}

\section{Streszczenie}

Intermedia nie odgrywają kluczowej roli w nauczaniu języka polskiego jako drugiego. Odpowiednio dobrane przykłady tekstów intermedialnych (np. Loesje, murale, sztuka z nurtu art\&science) i metody ich wykorzystania w praktyce edukacyjnej mogą sprawić, że kontakt z intermediami stanie się zarówno efektywnym komponentem kształtowania kompetencji językowych (języka 
edukacji szkolnej) i kulturowych oraz wartościowym przeżyciem estetycznym nawet dla uczniów z doświadczeniem migracji nieznających jeszcze dobrze języka polskiego.

Słowa kluczowe: język polski jako drugi; intermedia; język szkolny; kultura polska.

\section{INTERMEDIA IN THE PROCESS OF LEARNING ABOUT CULTURE BY THE STUDENTS EXPERIENCED IN MIGRATION}

\section{Su m m a r y}

Intermedia do not play a major part in teaching Polish as a second language. Properly selected examples of intermedial texts (Loesje, murals, art from the art\&science current) and methods to apply them in educational practice can ensure that contact with intermedia will be both a component for shaping language knowledge (the language of school education) and culture, and a valuable aesthetic experience even for the students experienced in migration whose knowledge of Polish is still scarce.

Key words: Polish as a second language; intermedia; school language; Polish culture. 